Marquette University

e-Publications@Marquette

Theology Faculty Research and Publications

Theology, Department of

$1-1-2003$

\title{
On the Polemical Nature of 2 (Slavonic) Enoch: A Reply to C. Böttrich
}

Andrei Orlov

Marquette University, andrei.orlov@marquette.edu

Author version. Journal for the Study of Judaism, Vol. 34, No. 3 (2003): 274-303. DOI: (C) 2003 Brill. Used with permission. 


\title{
On The Polemical Nature of 2 (Slavonic) Enoch: A Reply to C. Böttrich
}

\author{
Andrei A. Orlov \\ Theology Department, Marquette University \\ Milwaukee, WI
}

\begin{abstract}
In one of the recent issues of the Journal for the Study of Judaism $^{1}$ Christfried Böttrich offered his criticism ${ }^{2}$ of my article ${ }^{3}$ dedicated to the polemical developments in the shorter recension of the Melchizedek legend of 2 Enoch.
\end{abstract}

In his critical response $C$. Böttrich denied the possibility of any polemics not only in the Melchizedek story but also in the whole text of the Slavonic apocalypse. He stated that "polemics are not heard elsewhere in the narration; the picture of a still unified archaic mankind has no place for them." 4

Böttrich's strong negative reaction to the possibility of polemics in the Slavonic apocalypse must be understood in the context of his own scholarship. If such polemical developments do indeed exist, they pose a serious problem to Böttrich's research on 2 Enoch; this research has been for many years conducted without any recognition or consideration of such polemics. The existence of these polemical developments would reveal, therefore, the obvious flaw of his methodological approach, which has been unable to grasp the polemical character of the text. Moreover, if the investigation were to permission has been granted for this version to appear in e-Publications@ Marquette. Brill Academic Publishers does not grant permission for this article to be further copied/distributed or hosted elsewhere without the express permission from Brill Academic Publishers. 
proceed with the proper methodology, one which takes into consideration the polemical nature of 2 Enoch, a large number of Böttrich's conclusions on the theology, the history of the transmission, and the role of Jewish mystical traditions in the text would be dismissed as erroneous.

My reply to Christfried Böttrich, however, should not proceed solely as an exposition of the errors of his previous research, but should rather take a form of a further demonstration of the polemical nature of the Slavonic apocalypse. This chapter, therefore, will seek to investigate the Adamic polemics in 2 Enoch, one of the most important polemical developments taking place in the Slavonic apocalypse; this polemical development, unfortunately, completely escaped Böttrich's attention. ${ }^{5}$ By this investigation I will try to demonstrate that the polemics permeate the whole text and that without consideration of them any research on 2 Enoch ends inevitably in a blind alley.

\section{The Function of the Adamic Tradition in 2 Enoch}

Adam's story occupies a prominent place in 2 Slavonic (Apocalypse of) Enoch. The traditions pertaining to the first human can be found in all the sections of the book. ${ }^{6}$ In these materials Adam is depicted as a glorious angelic being, predestined by God to be the ruler of the earth, but falling short of God's expectations. Although a major bulk of Adamic materials belongs to the longer recension, which includes, for example, the lengthy Adamic narrative in chapters 30-32, the Adamic tradition is not confined solely to this recension. A number of important Adamic passages are also attested in the shorter recension. The extensive presence of Adamic materials in both recensions and their significance for the theology of the Slavonic apocalypse indicates that they are not later interpolations but are part of the original layer of the text.

It should be noted that such an extensive presence of Adamic materials in the intertestamental Enochic text is quite unusual. In the early Enochic circle, included in the composition known as 1 (Ethiopic) Enoch, Adam does not figure prominently. His presence in these materials is marginal and limited to a few insignificant remarks. Besides these few short references to the first humans, ${ }^{7}$ the early 
Enochic booklets are silent about the traditions associated with the protoplast. Moreover, Adam's image in 1 Enoch is quite different from the one attested in the Slavonic apocalypse. 1 Enoch's materials do not give any specific details about the elevated status of the protoplast. For example, the Animal Apocalypse (1 Enoch 85:3) depicts Adam as a white bull. Although white is a positive symbol in the imagery of $A n$. Ap. ${ }^{8}$ scholars note that, in general, this allegory does not indicate goodness or elevation, but rather lineage. ${ }^{9}$ Thus, in $A n$. Ap. all the sheep are white, even the blinded ones. The white color, therefore, does not serve as a sign of the elevated or angelic status of the protoplast. Sethites, for instance, are also depicted as white bulls. If the authors or editors of An. Ap. want to stress the angelic status of a character, they usually depict it in transformation from an animal into a human. Thus, in Ethiopic and Aramaic versions of An. Ap. (1 Enoch 89:36), Moses is portrayed as the one who was transformed from a sheep into a man during his encounter with God on Mount Sinai. Moses' "humanization" points to his transition to angelic status. The same process can be found in the Ethiopic version of An. Ap. (1 Enoch 89:9) where Noah's angelic metamorphosis is symbolically depicted as a transformation from a white bovid into a man. ${ }^{10}$ Such "humanization," however, was never applied to Adam in An. Ap.

The modest role which Adam plays in the early Enochic circle can be explained by several factors. Scholars previously observed that Enochic and Adamic traditions often offer contending explanations of the origin of evil in the world. ${ }^{11}$ The Enochic tradition bases its understanding of the origin of evil on the Watchers story, where the fallen angels corrupt human beings by passing on to them various celestial secrets. In contrast, the Adamic tradition traces the source of evil to Satan's disobedience and the transgression of Adam and Eve in Eden.

From the point of view of this long-lasting contention between Adamic and Enochic traditions, it might appear that the sudden occurrence of the large bulk of Adamic materials in 2 Enoch represents alien accretions skillfully interpolated into the original narrative during its long transmission in the Greek and Slavonic milieux. 
NOT THE PUBLISHED VERSION; this is the author's final, peer-reviewed manuscript. The published version may be accessed by following the link in the citation at the bottom of the page.

A closer examination of the text, however, shows that the presence of the Adamic tradition in the Slavonic apocalypse is not secondary or coincidental but has a profound conceptual value for the whole theological framework of the Slavonic apocalypse. It appears that the purpose of the extensive presence of Adamic materials in 2 Enoch can be explained through the assessment of Enoch's image in the text.

Scholars have previously noted that Enoch's figure, portrayed in the various sections of 2 Enoch, is more complex than in the early Enochic tractates of 1 Enoch. ${ }^{12}$ For the first time, the Enochic tradition seeks to depict Enoch, not simply as a human taken to heaven and transformed into an angel, but as a celestial being exalted above the angelic world. ${ }^{13}$ In this attempt, one may find the origins of another image of Enoch, very different from the early Enochic literature, which was developed much later in Merkabah mysticism-the concept of the supreme angel Metatron, "the Prince of the Presence." ${ }^{14}$ It is, therefore, possible that this new profile of the elevated Enoch in the Slavonic apocalypse can serve as an important clue to unriddling the mysteries of the extensive Adamic presence in 2 Enoch.

In 1987 Moshe Idel published an article ${ }^{15}$ in which he explored the role of the Adamic traditions in shaping the image of Enoch as the supreme angel Metatron. Although Idel's research dealt mainly with later rabbinic materials, it demonstrated that already in some pseudepigraphic accounts Enoch appears to be portrayed as a luminous counterpart of Adam who regained Adam's glory lost during the protoplast's transgression. ${ }^{16}$

Idel further suggested that Enoch's luminous metamorphosis attested in 2 Enoch 22 might also belong to the same tradition which views Enoch as the one who regained Adam's lost status and luminosity. He observed that to the best of his knowledge, "Enoch is the only ${ }^{17}$ living person for whom ... luminous garments, reminiscent of Adam's lost garments of light, were made."18

Philip Alexander, in his recent research, provides new insight into Idel's argument about the formative value of the Adamic tradition for the image of the elevated Enoch. Alexander points to a number of permission has been granted for this version to appear in e-Publications@Marquette. Brill Academic Publishers does not grant permission for this article to be further copied/distributed or hosted elsewhere without the express permission from Brill Academic Publishers. 
rabbinic passages in which the "supernatural radiance" of Adam's heavenly soul, which departed from him when he sinned, later returned to be reincarnated in Enoch. ${ }^{19}$ He further observes that

... behind these passages is a concept of Metatron as a divine entity first incarnate in Adam and then reincarnate in Enoch. Enoch, having perfected himself, in contrast to Adam, who sinned and fell, re-ascends to his heavenly home and takes his rightful place in the heights of the universe, above the highest angels ... Enoch thus becomes a redeemer figure-a second Adam through whom humanity is restored. ${ }^{20}$

It appears that the suggestions of scholars about the connection between Enoch and Adam are valid and deserve further investigation. It seems that the traces of the concept of Enoch as a second Adam can be detected already in 2 Enoch where Enoch assumes the glorious status of the protoplast.

It is also significant that in the Slavonic apocalypse the luminosity is not the only quality that Enoch inherited from Adam. In this text, Enoch acquired a whole host of roles and qualities which the Adamic narrative of the Slavonic apocalypse associates with the protoplast. In the course of these polemical appropriations, the elevated angelic status of the prelapsarian Adam, his luminosity, his wisdom, and his special roles as the king of the earth and the steward of all earthly creatures are transferred to the new occupant of the celestial realm, the patriarch Enoch, who, near the Lord's throne, is transformed into one of the glorious ones initiated into the highest mysteries by the Lord, becomes the "manager of the arrangements on the earth," and writes down "everything that nourished" on it.

Our further analysis will demonstrate that the traditions about the prelapsarian conditions of Adam provide an initial background for the polemical appropriations. The features of Adam's story, his roles and offices, are used in 2 Enoch as the building blocks ${ }^{21}$ for creating the new, celestial identity of the elevated Enoch.

This investigation must now turn to the text of the Slavonic Enoch in order to explore in detail these polemical developments.

\section{King of the Earth}

Journal for the Study of Judaism, Vol. 34, No. 3 (2003): pg. 274-303. DOI. This article is @ Brill Academic Publishers and permission has been granted for this version to appear in e-Publications@ Marquette. Brill Academic Publishers does not grant permission for this article to be further copied/distributed or hosted elsewhere without the express permission from Brill Academic Publishers. 
NOT THE PUBLISHED VERSION; this is the author's final, peer-reviewed manuscript. The published version may be accessed by following the link in the citation at the bottom of the page.

2 Enoch 30:12 describes Adam as the king of the earth. ${ }^{22}$ This honorable role in 2 Enoch, as in the Genesis account, represents not merely an impressive metaphor but presupposes specific duties which demonstrate Adam's royal status. Most of these activities have biblical roots. ${ }^{23}$ From 2 Enoch 58:3, we learn that the Lord appointed Adam over

...everything [as king], and he subjected everything to him in subservience under his hand, both the dumb and the deaf, to be commanded and for submission and for every servitude. So also to every human being. The Lord created mankind to be the lord of all his possessions. ${ }^{24}$

This description of Adam's duties corresponds to the account found in Gen 1:26-30 where God gives Adam dominion over "everything that has the breath of life."

As in Gen 2:19-20, one of the important functions of the new appointed king is the registration of all the "possessions," i.e., all the living creatures of the earth given to his stewardship through the act of their naming. 2 Enoch 58 states that

...the Lord came down onto the earth [on account of Adam] and he inspected all his creatures which he himself had created in the beginning of the thousand ages and then after all those he had created Adam. And the Lord summoned all the animals of the earth and all reptiles of the earth and all the birds that fly in the air, and he brought them all before the face of our father Adam, so that he might pronounce names for all the quadrupeds; and [Adam] named everything that lives on the earth. ${ }^{25}$

Giving names here, just as in the Genesis account, also designates Adam's dominion over "everything that lives on the earth." This dominion, however, as in the Biblical account, is supervised by the Lord. The whole picture indicates that the author of 2 Enoch understands Adam's "kingship" as the management of God's property. ${ }^{26}$ It is significant that the Slavonic apocalypse defines Adam's role as "the lord of all God's possessions."27

In the Slavonic apocalypse, however, the governing role of Adam as the lord of all God's possessions is challenged by the account of Enoch's kingship and his role as "the manager of the arrangements 
on the earth." This new role of Enoch vividly recalls the former royal status of the protoplast.

The first hint about Enoch's role as the governing power on earth comes from chapter 39 where Enoch relates to his children the details of his encounter with the divine anthropomorphic extent, identified in the text as the Lord's "Face." Enoch's description provides a series of analogies in which the earthly Enoch compares his face and parts of his body with the attributes of the Lord's Face and body. At the end of his description, Enoch delivers the following conclusion:

Frightening and dangerous it is to stand before the face of the earthly king, terrifying and very dangerous it is, because the will of the king is death and the will of the king is life. How much more terrifying [and dangerous] it is stand before the face of the King of earthly kings and of the heavenly armies....Who can endure that endless misery? ${ }^{28}$

In the light of the overall logic of the patriarch's speech, in which the "attributes" of the Lord have been compared with Enoch's "attributes," it becomes clear that the earthly king of the story is Enoch himself. This interpretation is "confirmed" by the manuscripts of the shorter recension which directly identify Enoch as the earthly king:

And now my children, listen to the discourses of an earthly king. It is dangerous and perilous to stand before the face of the earthly king, ${ }^{29}$ terrifying [and very perilous] it is... ${ }^{30}$

The designation of Enoch as the royal/governing power on earth is not confined solely to the passage found in chapter 39. 2 Enoch 46:1-2 (the longer recension) also recounts the tradition about Enoch as the earthly king. There again Enoch refers to his royal status indirectly in third person. ${ }^{31}$

The significant feature of Enoch's designation as the earthly king in the Slavonic apocalypse is that this text understands Enoch not as one of the earthly kings, but as the king of the earth who, in a manner similar to the protoplast, supervises all arrangements on the earth. This exclusive role is hinted at in 2 Enoch 64, which depicts the patriarch's address to the princes of the people as they prostrate themselves before him. This role is also intimated in chapter 43 of the shorter recension and a similar passage from 2 Enoch found in the permission has been granted for this version to appear in e-Publications@Marquette. Brill Academic Publishers does not grant permission for this article to be further copied/distributed or hosted elsewhere without the express permission from Brill Academic Publishers. 
Slavonic collection the "Just Balance" (Slav. "Merilo Pravednoe"), where Enoch is described as the manager of the earth:

....and behold my children, I am the manager of the arrangements on earth, I wrote (them) down. and the whole year I combined and the hours of the day. And the hours I measured: and I wrote down every seed on earth. And I compared every measure and the just balance I measured. And I wrote (them) down, just as the Lord commanded ... ${ }^{32}$

It should be noted that the definition of Enoch as the king is a unique motif in early Enochic materials. ${ }^{33}$ In 1 Enoch, Jubilees, and the Book of Giants, the patriarch is often described as an intercessor, a visionary, a scribe, an expert in secrets, but never directly as a king. ${ }^{34}$ It, therefore, becomes apparent that the royal/governing functions of Enoch are construed in the Slavonic apocalypse in the context of its polemical response to the Adamic tradition; it serves as a counterpart to the royal status of the protoplast. It is not therefore coincidental that in this situation some duties of Adam in his office of the king of the earth become also transferred to the new occupant of this office, the seventh antediluvian patriarch. In chapters 39 and 43, Enoch's introductions as the king and the manager of the earth are followed with lengthy accounts of Enoch's activities involving measuring everything on earth. Right after Enoch is defined as the earthly king in 2 Enoch 39, the patriarch tells his children:

...And everything that is nourished on the earth I have investigated and written down, and every seed, sown and not sown, which grows from earth, and all the garden plants, and all the grasses, and all the flowers, and their delightful fragrances and their names... I measured all the earth, and its mountains and hills and fields and woods and stones and rivers, and everything that exist.... ${ }^{35}$

It appears that the functions of Enoch in his role as the king/manager of the earth include, just as in the role of Adam, the duty registering the created order. Like Adam who "named" everything that lives on the earth Enoch in his turn writes down "every seed on the earth." 36

It is important that Enoch's "stewardship" over the created order, akin to Adam's duties, also includes the obligation to protect and care for the animals. In 2 Enoch 58-59, the protoplast's responsibilities pertaining to the animals are transferred to the seventh antediluvian patriarch and his descendants. permission has been granted for this version to appear in e-Publications@ Marquette. Brill Academic Publishers does not grant permission for this article to be further copied/distributed or hosted elsewhere without the express permission from Brill Academic Publishers. 
It is noteworthy that both accounts, the story of Adam's naming of animals and Enoch's instructions to his children about the protection of animals, are located in the same chapter of the Slavonic apocalypse. 2 Enoch 58 depicts the Lord summoning all creatures of the earth and bringing them before Adam that the first human might name them. This story then continues with Enoch's instructions to his children about the special care for animals whose souls will testify against human beings at the great judgment if they treat them unjustly. This account, which substitutes one steward of God's earthly creatures for another, fits perfectly into the pattern of the Adamic polemics found in the Slavonic apocalypse.

In Weltweisheit, Menschheitsethik, Urkult, C. Böttrich drew attention to the patriarch's designation as the earthly king. ${ }^{37}$ Unfortunately, he failed to recognize the polemical meaning of this royal title in the original argument of the Slavonic apocalypse and dismissed it as a later interpolation. Böttrich's attempt to illuminate the origins of Enoch's royal imagery through the reference to the late rabbinic text Hayye Hanokh from Sefer haYashar is problematic. ${ }^{38}$ In light of our hypothesis about the Adamic provenance of Enoch's royal title in the Slavonic apocalypse, such dubious associations are not necessary.

\section{Angelic Veneration}

It is difficult to overestimate the value for our discussion of an article published by Michael Stone in 1993. ${ }^{39} \mathrm{M}$. Stone's illuminating study reveals that the argument with the Adamic tradition in the Slavonic apocalypse includes, not only the internal debates based on 2 Enoch's depictions of the protoplast, but also the intertextual polemics with the Adamic traditions attested in the primary Adam books. ${ }^{40}$ The fact that these Adamic traditions are already re-written in the Slavonic apocalypse, as the deeds and functions of the protoplast are transferred to Enoch without any reference to their original "proprietor," serves as strong evidence to the scope of the polemical intentions of 2 Enoch's authors.

M. Stone's article investigates an important motif preserved in chapters 21-22 of the Slavonic apocalypse. The story depicts angels 
bringing Enoch to the edge of the seventh heaven. By the Lord's command, the archangel Gabriel invites the patriarch to stand in front of the Lord forever. Enoch agrees and Archangel Gabriel carries him to the "Face" of the Lord where the patriarch does obeisance to God. God then personally repeats the invitation to Enoch to stand before him forever. After this invitation, Archangel Michael brings the patriarch to the front of the face of the Lord. The Lord then tells his angels, sounding them out: "Let Enoch join in and stand in front of my face forever!" In response to this address, the Lord's glorious ones do obeisance to Enoch saying, "Let Enoch yield in accordance with your word, O Lord!"41 After that the patriarch's earthly garments were removed by Archangel Michael, he was anointed with shining oil and became like one of the glorious ones. ${ }^{42}$

M. Stone observes that the story found in 2 Enoch 21-22 recalls the account of Adam's elevation and his veneration by angels found in Armenian, Georgian, and Latin versions of the Life of Adam and Eve. ${ }^{43}$ These versions depict God's creation of Adam in his image. Archangel Michael brought the first human and had him bow down before God's face. God then commanded all the angels to bow down to Adam. All the angels agreed to venerate the protoplast except Satan (and his angels) who refused to bow down before Adam, because the first human was "younger" than ("posterior" to) Satan.

M. Stones notes that, aside from the motifs of Adam's elevation and his veneration by angels, the author of 2 Enoch appears to be also aware of the motif of angelic disobedience and refusal to venerate the first human. M. Stone draws the reader's attention to the phrase "sounding them out," found in 2 Enoch 22:6, which another translator of the Slavonic text rendered as "making a trial of them." $44 \mathrm{M}$. Stone rightly notes that the expressions "sounding them out" or "making a trial of them" imply here that it is the angels' obedience that is being tested. ${ }^{45}$

Comparing the similarities between Adamic and Enochic accounts, M. Stone observes that the order of events in 2 Enoch exactly duplicates the order found in the primary Adam books since both sources know three chief events: ${ }^{46}$ permission has been granted for this version to appear in e-Publications@ Marquette. Brill Academic Publishers does not grant permission for this article to be further copied/distributed or hosted elsewhere without the express permission from Brill Academic Publishers. 
NOT THE PUBLISHED VERSION; this is the author's final, peer-reviewed manuscript. The published version may be accessed by following the link in the citation at the bottom of the page.

I. $L A E$ : Adam is created and situated in heaven.

2 Enoch: Enoch is brought to heaven.

II. $L A E$ : Archangel Michael brings Adam before God's face. Adam does obeisance to God.

2 Enoch: Archangel Michael brings Enoch before the Lord's Face. Enoch does obeisance to the Lord.

III. LAE: God commands the angels to bow down. All the angels do obeisance. Satan and his angels disobey.

2 Enoch: "The rebellion in the Adam events is assumed. God tests whether this time the angels will obey. The angels are said to bow down and accept God's command." 47

M. Stone concludes that the author of 2 Enoch 21-22 was cognizant of the traditions resembling ${ }^{48}$ those found in Armenian, Georgian, and Latin versions of the Life of Adam and Eve. ${ }^{49} \mathrm{He}$ also stresses that these traditions did not enter 2 Enoch from the Slavonic Life of Adam and Eve, because this form of tradition does not occur in the Slavonic recension of the primary Adam book. ${ }^{50}$

It appears that the Adamic tradition from chapter 22 is not an interpolation, but belongs to the original core of the Slavonic apocalypse. Two significant features found in 2 Enoch seem to indicate that the tradition of angelic veneration is interwoven into the original fabric of the text. The first is evidenced in chapter 7 of the Slavonic apocalypse. 2 Enoch 7:3 depicts Enoch carried by angels to the second heaven. There the patriarch sees the condemned angels kept as prisoners awaiting the "measureless judgment." Enoch's angelic guides explain to him that the prisoners are "those who turned away from the Lord, who did not obey the Lord's commandments, but of their own will plotted together and turned away with their prince and with those who are under restraint in the fifth heaven." 51 The story further continues with angelic veneration: the condemned angels bow down to Enoch asking for his intercession: "Man of God, pray for us to the Lord!"52

It is possible that this passage about the group of the condemned angels is an allusion to the motif of angelic veneration found in 2 Enoch 22 and in the primary Adam books. permission has been granted for this version to appear in e-Publications@Marquette. Brill Academic Publishers does not grant permission for this article to be further copied/distributed or hosted elsewhere without the express permission from Brill Academic Publishers. 
NOT THE PUBLISHED VERSION; this is the author's final, peer-reviewed manuscript. The published version may be accessed by following the link in the citation at the bottom of the page.

Three details of the story from 2 Enoch 7 seem to support this interpretation:

a. In 2 Enoch 7, just as in the Adamic accounts, the sin of the imprisoned angels is disobedience to the Lord's commandments.

b. The agents of the rebellion are a group of angels with "their prince." This recalls the information found in the Adamic accounts where not only Satan, but also other angels under him, refuse to venerate Adam. The longer recension of 2 Enoch 18:3 directly identifies the prisoners of the second heaven as the angels of Satanail. ${ }^{53}$

c. The imprisoned angels bow down before man (Enoch). An additional important detail here is that the patriarch is addressed by the fallen angels as a "man"-"a man of God."

This act of angelic bowing before Enoch in the second heaven might anticipate later angelic obeisance the patriarch received in chapter 22 of the Slavonic apocalypse.

The second evidence demonstrating that the theme of angelic bowing from chapter 22 is deeply imbedded in the original theological framework of the Enochic writing is its connection with the Enochic title "Youth" or "Lad" found in some Slavonic MSS of 2 Enoch.

\section{Youth}

We have already seen that the authors of 2 Enoch are responsible for creating the new roles and titles of Enoch which are absent in the early Enochic treatises of 1 Ethiopic Enoch but can be found in the later Merkabah mysticism. One of such titles is "Youth" which becomes one of the favorite designations of Metatron in the Merkabah literature.

Before proceeding to the analysis of the title "Youth" in the Slavonic text and its connection with the Adamic tradition, a short excursus into the later rabbinic materials is necessary.

Recently Gary Anderson demonstrated that the Adamic story of angelic veneration and opposition to humanity played a prominent role in rabbinic literature. ${ }^{54}$ In his article Anderson draws attention to the

Journal for the Study of Judaism, Vol. 34, No. 3 (2003): pg. 274-303. DOI. This article is @ Brill Academic Publishers and permission has been granted for this version to appear in e-Publications@ Marquette. Brill Academic Publishers does not grant permission for this article to be further copied/distributed or hosted elsewhere without the express permission from Brill Academic Publishers. 
NOT THE PUBLISHED VERSION; this is the author's final, peer-reviewed manuscript. The published version may be accessed by following the link in the citation at the bottom of the page.

account found in 3 Enoch 4 where the Adamic motif of angelic veneration, in a manner similar to 2 Enoch 22, was applied to EnochMetatron.

3 Enoch 4:1-10 depicts Rabbi Ishmael questioning his celestial guide Metatron about his name "Youth." The passage reads:

R. Ishmael said: I said to Metatron: "... you are greater than all the princes, more exalted than all the angels, more beloved than all the ministers ... why, then, do they call you 'Youth' in the heavenly heights?" He answered:

"Because I am Enoch, the son of Jared ... the Holy One, blessed be he, appointed me in the height as a prince and a ruler among the ministering angels. Then three of ministering angels, Uzzah, Azzah, and Azael, came and laid charges against me in the heavenly height. They said before the Holy One, blessed be He, "Lord of the Universe, did not the primeval ones give you good advice when they said, Do not create man! ${ }^{55}$... And once they all arose and went to meet me and prostrated themselves before me, saying "Happy are you, and happy your parents, because your Creator has favored you. Because I am young in their company and mere youth among them in days and months and years-therefore they call me 'Youth'."56

Commenting on this passage, G. Anderson suggests that if "we remove those layers of the tradition that are clearly secondary ... we are left with a story that is almost identical to the analog we have traced in the Adam and Eve literature and II Enoch." ${ }^{57}$ He further notes that the acclamation of Enoch as "Youth" in Sefer Hekhalot is intriguing since the reason 3 Enoch supplies for this title is deceptively simple and straightforward: "Because I am young in their company and a mere youth among them in days and months and yearstherefore they call me 'Youth.'" G. Anderson proposes that the title might have Adamic origins since the explanation for the epithet "youth" recalls the reason for the angelic refusal to worship Adam in the Vita on the basis of his inferiority to them by way of his age. ${ }^{58}$

G. Anderson's hypothesis that the origin of the title "Youth" is connected with the appropriation of the Adamic tradition is crucial to the current investigation.

It is interesting that in some manuscripts of the Slavonic Enoch the seventh antediluvian patriarch is also often addressed as "youth." 59 Despite the fact that this designation occurs only in several Slavonic manuscripts, the author of the recent English translation, Francis

Journal for the Study of Judaism, Vol. 34, No. 3 (2003): pg. 274-303. DOI. This article is @ Brill Academic Publishers and permission has been granted for this version to appear in e-Publications@ Marquette. Brill Academic Publishers does not grant permission for this article to be further copied/distributed or hosted elsewhere without the express permission from Brill Academic Publishers. 
Andersen, considered this reading as the original. ${ }^{60} \mathrm{He}$ was also the first scholar to propose that Enoch's designation as "Youth" in 2 Enoch recalls the identical title of Metatron attested in 3 Enoch and other Hekhaloth writings. ${ }^{61}$ In his commentary to the English translation of 2 Enoch in OTP, Andersen wrote:

The remarkable reading yunoše [youth], clearly legible in A, supports the evidence of $\mathrm{V}$, which has this variant four times (not here), and of other MSS, that there was a tradition in which Enoch was addressed in this way. The similarity to the vocative enoše [Enoch] might explain the variant as a purely scribal slip. But it is surprising that it is only in address, never in description, that the term is used. The variant jenokhu is rare. There is no phonetic reason why the first vowel should change to ju; junokhu is never found. But it cannot be a coincidence that this title is identical with that of Enoch (=Metatron) in 3 Enoch. ${ }^{62}$

It is notable that several important occurrences of the title "Youth" in 2 Enoch come from the mouth of angels. Thus in chapter 9 of the shorter recension, an angelic being accompanying Enoch on his way through the heavenly realm addresses him as "youth:" "This place has been prepared, Youth, for the righteous ...."63 Later in chapter 10, one can hear the same address again: "this place, Youth, has been prepared for those who practice godless uncleanness on the earth ...."64 These angelic addresses are consistent with the Adamic and Merkabah accounts in which angelic beings point to Adam/Enoch's young age.

According to the Merkabah tradition, God also likes to address Enoch-Metatron as "Youth." In 3 Enoch 3, when R. Ishmael asks Metatron "What is your name?" Metatron answers, "I have seventy names, corresponding to the seventy nations of the world ... however, my King calls me 'Youth'."65 The designation of Enoch as "Youth" seems to signify here the special relationship between the Holy One and Metatron. One can see the beginning of this tradition already in 2 Enoch where in chapter 24 of the shorter recension the following tradition can be found:

And the Lord called me (Enoch) and he placed me to himself closer than Gabriel. And I did obeisance to the Lord. And the Lord spoke to me "Whatever you see, Youth, things standing still and moving about were brought to perfection by me. and not even to angels have I explained my secrets...as I am making them known to you today...."66 permission has been granted for this version to appear in e-Publications@ Marquette. Brill Academic Publishers does not grant permission for this article to be further copied/distributed or hosted elsewhere without the express permission from Brill Academic Publishers. 
NOT THE PUBLISHED VERSION; this is the author's final, peer-reviewed manuscript. The published version may be accessed by following the link in the citation at the bottom of the page.

It is significant that the title "youth" here is tied to the motif of human superiority over angels, which plays a prominent role in the primary Adam books where God orders his angels to bow down before humanity.

Finally, we must note that several important readings of "youth" in the materials associated with the Slavonic Enoch can be found in the Vienna Codex. ${ }^{67}$ In this manuscript Enoch is addressed by the Lord as "youth" 68 in the context of angelic veneration:

And the Lord with his own mouth called me [Enoch] and said: Be brave, Youth! ${ }^{69}$ Do not be frightened! Stand up in front of my face forever. And Michael, the Lord's archistratig, brought me in the front of the Lord's face. And the Lord tempted his servants and said to them: "Let Enoch come up and stand in the front of my face forever." And the glorious ones bowed down and said: "Let him come up!"70

In conclusion, it should be noticed that our analysis revealed that several important readings pertaining to the Adamic polemics can be found in the manuscripts of the shorter recension. It does not follow, however, that these readings are secondary and not original. The rehabilitation of the longer recension, as well as the reaffirmation of its value in recent scholarship, should not lead to the automatic rejection of everything in the shorter recension as inauthentic and secondary. The mere subscription to one of the recensions deceptively oversimplifies the problem of asserting the original text. The task is more complicated and necessarily involves a careful investigation of the theological intentions of the authors and editors of the text. Almost three decades ago F. Andersen warned students of 2 Enoch against jumping to simplistic and hasty conclusions. He noted that "all of the materials calls for reassessment .... In the present state of our knowledge, the genuineness of any disputed passage is difficult to judge." ${ }^{71}$ His prudent advice still remains valuable today.

\section{The Hunger Motif}

The previous analysis demonstrated that the author(s) of the Slavonic apocalypse were cognizant of the motifs and themes similar to those found in the primary Adam books. One of the prominent 
Adamic motifs absent in the Biblical account but present in the later extrabiblical traditions is the theme of Adam and Eve's hunger after their eviction from Eden to earth. ${ }^{72}$

The primary Adam books begin their stories with depicting the expulsion of the first humans from the Garden. The narrative continues with describing the hunger the first humans experienced as they found themselves on earth. It seems that the cause of their hunger was not the absence of food on earth, but the dining habits of the first humans, who were used to the celestial nourishment during their stay in Paradise. It is, therefore, significant that the Armenian, Georgian, and Latin versions of the primary Adam books emphasize the difference between the two foods: the angelic food which Adam and Eve ate in the paradise and the food that lies before them on the earth. ${ }^{73}$

In 2 Enoch the story of the first humans' hunger takes a new polemical form. The second part of 2 Enoch depicts the patriarch who, just like Adam and Eve, was transported from heaven to earth. This time, however, the transition is pleasant: Enoch is not punitively expelled from heaven, like Adam, but sent by God on a short trip to instruct his children. From 2 Enoch 56:2 we learn that during Enoch's instructions, Methuselah asks his father a blessing, so that he may prepare some food for him to eat. The patriarch answers his son in the following manner:

Listen, child! Since the time when the Lord anointed me with the ointment of his glory, food has not come into me, and earthly pleasure my soul does not remember, nor do I desire anything earthly (2 Enoch 56:2 the longer recension).

In the shorter recension of 2 Enoch, the patriarch's rejection of food is even more decisive:

Listen my child! Since the time when the Lord anointed me with ointment of my glory, it has been horrible for me, and food is not agreeable to me, and I have no desire for earthly food. ${ }^{74}$

The important detail that connects this Enochic account to the account found in the Armenian, Georgian, and Latin primary Adam books is their emphasis on the fact that it is the earthly food that is unsuitable permission has been granted for this version to appear in e-Publications@ Marquette. Brill Academic Publishers does not grant permission for this article to be further copied/distributed or hosted elsewhere without the express permission from Brill Academic Publishers. 
for those who just came from the celestial realm. The account found in these versions of the primary Adam books also stresses this fact. They inform that Adam and Eve "did not find food like the food by which they had been nourished in the Garden." Eve's discourse found in 4:2 again emphasizes this difference between earthly and celestial food, referring to earthly food as nourishment for the beasts. ${ }^{75}$

These similarities suggest that the tradition found in 2 Enoch 56:2 might represent a part of the polemics with the Adamic traditions in the Slavonic apocalypse. Here Enoch is depicted as superior to Adam and Eve, who must accept the earthly food as the sign of the Fall and their permanent transition to the lower realm.

It should be also noted that it is unlikely that this tradition entered 2 Enoch from the Slavonic Life of Adam and Eve, since the Slavonic Vita does not attest to the traditions about earthly and celestial food.

\section{The Motif of the Divine Face}

Our previous investigation of the motif of angelic veneration showed that one of the concentrated elaborations of Adamic polemics in 2 Enoch is found in chapter 22, which depicts the climax of Enoch's celestial trip and his luminous metamorphosis near the Throne of Glory. The partiarch's transition to the new, celestial identity found in this part of the text is therefore convenient for appropriating the Adamic tradition about the luminous condition of the protoplast.

The motif of the divine Face is important to linking Enoch's glorious condition with the former luminosity of Adam. Enoch's luminous metamorphosis takes its place in front of the Lord's glorious "extent," labeled in 2 Enoch 22 and 39 as the Lord's "Face."76 From 2 Enoch 22 we learn that the vision of the divine "Face" had dramatic consequences for Enoch's appearance. His body endured radical changes as it became covered with the divine light. This encounter transformed Enoch into a glorious angelic being. The text says that after this procedure Enoch became like one of the glorious ones, and there was no observable difference. ${ }^{77}$ This phrase describes Enoch's transition to his new celestial identity as "one of the glorious ones." 
During this transition in front of the Lord's face, Enoch's own "face" became radically altered and the patriarch acquired a new glorious "visage" which reflected the luminosity ${ }^{78}$ of the Lord's Panim. ${ }^{79}$ The important link that connects this new condition of Enoch with the condition of the glorious Adam is the theme of the new creation after the Lord's Face. It has been shown that the Face in 2 Enoch 22 represented the cause and the prototype after which the new celestial identity of Enoch was formed. The new creation after the Face signifies here the return to the prelapsarian condition of Adam, who also was "modeled" after the Face of God. Support for this view can be found in 2 Enoch 44:1 where one learns that the protoplast was also created after the Face of God. The text says that "the Lord with his own two hands created mankind; in a facsimile of his own face, both small and great, the Lord created [them]." 80 It is intriguing that 2 Enoch departs here from the canonical reading attested in Gen 1:26-27 where Adam was created, not after the face of God, but after His image (tselem). F. Andersen observes that 2 Enoch's "idea is remarkable from any point of view.... This is not the original meaning of tselem.... The text uses podobie lica [in the likeness of the face], not obrazu or videnije, the usual terms for "image." 81

It is clear, however, that this reading did not arise in the Slavonic environment, but belonged to the original argument of 2 Enoch where the creation of the luminous protoplast after the Face of the Lord corresponds to a similar angelic "creation" of the seventh antediluvian patriarch. There is almost no doubt that, in the view of the information about Adam's glorious angelic nature attested in 2 Enoch 30:11, the author of the Slavonic apocalypse tries to connect the theme of Adam's creation with the motif of the glorious Face of the Lord.

Regrettably, Böttrich did not recognize the pivotal role of the imagery of the divine Face in the original argument of the Slavonic apocalypse and rejected the descriptions of the Lord's Face in 2 Enoch 22 and 39 as later interpolations. ${ }^{82}$ This rejection had, in my judgment, dramatic consequences for Böttrich's research and his ability to discern the theology of the text in general and the meaning of the Adamic traditions in 2 Enoch in particular. The tradition of the Divine Face represents a nexus through which several significant permission has been granted for this version to appear in e-Publications@Marquette. Brill Academic Publishers does not grant permission for this article to be further copied/distributed or hosted elsewhere without the express permission from Brill Academic Publishers. 
polemical trajectories of the text are interwoven together. One of these trajectories is the connection between the traditions of Adam's cosmic body in 2 Enoch 30:8-11 and the Shicur Qomah tradition presented in 2 Enoch 39, which depicts Enoch as the measurer of the divine body. ${ }^{83}$ This important connection completely escaped Böttrich's attention and undermined the credibility of his later research on the cosmic body of Adam. ${ }^{84}$

\section{Oil from the Tree of Life}

Another Adamic motif in the story of Enoch's transformation is the luminous oil, which causes the patriarch's glorious metamorphosis. 2 Enoch 22:9 portrays Archangel Michael extracting Enoch from his clothes and anointing him with delightful oil. The text tells that the oil's appearance was "greater than the greatest light and its ointment is like sweet dew, and the fragrance [like] myrrh; and it is like rays of the glittering sun." 85 The anointing with the oil causes the patriarch's transformation from the garments of skin to the luminous garment of an immortal angelic being, one of the glorious ones.

It appears that that the oil used in Enoch's anointing comes from the Tree of Life, which in 2 Enoch 8:3-4 is depicted with a similar symbolism. 2 Enoch 8:3-4 tells that "... the tree [of life] is indescribable for pleasantness and fine fragrance, and more beautiful than any (other) created thing that exists. And from every direction it has an appearance which is gold-looking and crimson, and with the form of fire." 86 The shorter recension also refers to a second, olive tree near the first one "flowing with oil continually." 87

It should be noted that the oil anointing of Enoch is a unique motif in the Enochic tradition. Enoch's approach to the throne in the Book of Watchers and his transformation into the Son of Man in the Book of the Similitudes do not involve anointing with or any usage of oil. Later "Enochic" traditions are also silent about oil. For example, the account of Metatron's transformation in 3 Enoch does not mention any anointing with oil.

Yet while unknown in the Enochic literature, the motif of anointing with the oil from the Tree of Life looms large in the Adamic permission has been granted for this version to appear in e-Publications@ Marquette. Brill Academic Publishers does not grant permission for this article to be further copied/distributed or hosted elsewhere without the express permission from Brill Academic Publishers. 
tradition. Chapter 35(9) of the primary Adam books contains the story of Adam's sickness. The patriarch finds himself in great distress and pain. Trying to find a cure, Adam sends Eve and Seth to paradise so they can bring the oil of the Tree of Life that will relieve his illness. Their mission, however, is unsuccessful. Archangel Michael refuses to give the oil to Eve and Seth, telling them that the oil will be used "when the years of the end are filled completely" for those who "be worthy of entering the Garden." 88

There are several corresponding characteristics that can be detected in the Adamic and Enochic accounts:

1. The purpose of the anointing is similar in both traditions. Its function is the "resurrection of Adam's body" 89 e.g., the reversal of the earthly fallen condition into the incorruptible luminous state of the protoplast. It is not coincidental that in 2 Enoch 22 oil anointing transforms Enoch into a luminous angelic being. As has been already noted, it recalls the description of the protoplast in 2 Enoch 30:11 as a glorious angelic being.

2. The subject of the anointing is also identical. In 2 Enoch and in the primary Adam books, the oil is used (or will be used) for transforming the righteous ones in their transition to the angelic state in the celestial realm. In the primary Adam books, the oil is prepared for those who "be worthy of entering the Garden."90 M. Stone observes that 2 Enoch also "knows an anointing with the heavenly perfumed oil that brings about a transformation of the righteous." 91

The same situation is also attested in 3 Baruch, where the reward of the righteous is oil. $\mathrm{H}$. Gaylord notes that this theme in 3 Baruch has a connection with the Adamic tradition. He observes that "by his disobedience Adam lost 'the glory of God' (4:16[G]), which may have been comparable to that of angels (cf. 13:4[S]). The reward of the righteous is oil, possibly the sign of the glory of God, which the angel-guide promises to show Baruch several times in this text $(6: 12 ; 7: 2 ; 11: 2$; $16: 3[\mathrm{~S}])$. It is hardly accidental that there are traditions that Adam sought to receive the 'oil of mercy' at the point of death, and that Enoch was transformed by the 'oil of his glory'..."92 
3. It is important that in 2 Enoch and in the primary Adam books a person in charge of oil is the archangel Michael. ${ }^{93}$ In 2 Enoch 22 he anoints Enoch with shining oil causing his luminous metamorphosis. In 3 Baruch 15:1 Michael brings oil to the righteous. ${ }^{94}$ In the primary Adam books he also seems to be in charge of oil since it is he who declines giving Seth the oil for healing Adam.

4. It is intriguing that 2 Enoch and the primary Adam accounts refer to the flowing of the oil. Thus, the Georgian $L A E$ 36(9):4 relates that "... (God) will send his angel to the Garden where the Tree of Life is, from which the oil flows out, so that he may give you a little of that oil."95 2 Enoch 8:5 seems to attest to the same tradition: "and another tree is near it, an olive, flowing with oil continually." $M$. Stone notes that "it is striking that 2 Enoch highlights the flowing of the oil, just like the Adam books." 96

These similarities show that the motif of the oil from the Tree of Life in 2 Enoch might have Adamic provenance. It is unlikely that this tradition is a later interpolation. Attested in both recensions, it plays a pivotal role in the scene of Enoch's luminous metamorphosis.

\section{"The One Who Carried Away the Sin of Humankind"}

It has been mentioned earlier that in later Jewish mysticism Metatron was viewed as a divine being first incarnated in Adam and then in Enoch, who re-ascended to the protoplast's heavenly home and took his rightful place in the heights of the universe. P. Alexander observes that "Enoch thus becomes a redeemer figure-a second Adam through whom humanity is restored." 97 It appears that this theological motif of Enoch's redeeming role is already developed in 2 Enoch.

In chapter 64 of the longer recension of the Slavonic apocalypse, the "astounding encomium" can be found which, in the view of one of 2 Enoch's translators, "could hardly please a Christian or a Jew."98 The chapter depicts a prostration of "the elders of the people" and "all the community" before Enoch at the place of his permission has been granted for this version to appear in e-Publications@ Marquette. Brill Academic Publishers does not grant permission for this article to be further copied/distributed or hosted elsewhere without the express permission from Brill Academic Publishers. 
second departure to heaven. The people who came to bow down before the patriarch delivered to Enoch the following address:

O our father, ${ }^{99}$ Enoch! May you be blessed by the Lord, the eternal king! And now, bless your [sons], and all the people, so that we may be glorified in front of your face today. For you will be glorified in front of the face [of the Lord for eternity], because you are the one whom the Lord chose in preference to all the people upon the earth; and he appointed you to be the one who makes a written record of all his creation, visible and invisible, and the one who carried away the sin of mankind (2 Enoch 64:4-5). ${ }^{100}$

An important detail in this address is Enoch's designation as "the one who carried away the sin of [hu]mankind." This depiction of the patriarch as a redeemer is intriguing. But what kind of sin was Enoch able to carry away?

Böttrich argues that the description of Enoch as the one who carried away the sins of humankind reflects not the reality but only the expectation of the "elders of the people." He stresses that 2 Enoch absolutely rejects the idea of intercession before God, ${ }^{101}$ pointing to the passage in chapter 53 where the patriarch warns his children that he will not be able to help them on the day of judgment, since no one can help relieve another person's $\sin .{ }^{102}$

Unfortunately, Böttrich's observations, based on a faulty methodology, miss the gist of the argument in chapter 64. Oblivious to Adamic polemics in the text, he fails to notice a crucial detail: in 2 Enoch 64 the "elders of the earth" define Enoch not as the one who will carry away the sin of humankind, but as the one who already carried away this $\sin { }^{103}$ The emphasis on the already accomplished redemptive act provides an important clue to understanding the kind of sin Enoch was able to erase. The focus here is not on the individual sins of Enoch's descendents, but on the primeval sin of humankind. ${ }^{104}$ Therefore, it becomes apparent that the redeeming functions of the patriarch are not related to his possible intercession for the sins of his children, the fallen angels or the "elders of the earth," as Böttrich suggested. Rather they pertain to the sin of the protoplast which the patriarch was able to "carry away" by his righteousness, ascension, and transformation. Accordingly, Enoch has already accomplished his role as the "redeemer" of humanity through his luminous metamorphosis near the throne of glory. ${ }^{105}$ Humanity has been permission has been granted for this version to appear in e-Publications@ Marquette. Brill Academic Publishers does not grant permission for this article to be further copied/distributed or hosted elsewhere without the express permission from Brill Academic Publishers. 
redeemed in him, and this redemption gives hope to other righteous ones, who will later attain the paradisal condition. The significant detail that confirms Enoch's unique redeeming role is that, unlike in chapter 53 where he opposes the idea of intercession, in 2 Enoch 64-65 he does not object to the idea that he is able to carry away the sin of humankind.

Enoch's response to the people's address, which occupies the following chapter 65, provides additional support for interpreting the sin Enoch was able to carry away as related to the transgression of the protoplast. It is not coincidental that the patriarch starts his response with paraphrasing the account of Adam's creation, telling that the Lord "constituted man in his own form, in accordance with a similarity."106 He further relates that the Lord gave the protoplast "eyes to see, and ears to hear, and heart to think, and reason to argue."107 Some elements of this part of the paraphrase allude to the details of the protoplast's marvelous creation found in 2 Enoch 30:9, namely to some of his properties (seeing, hearing, reasoning) given to Adam at his creation.

Enoch concludes his reply to the people with the theme of the restoration of humanity to its prelapsarian "paradisal" condition, further indicating that the whole account revolves around the patriarch's role in the removal of Adam's sin. It is logical, therefore, that this message of hope comes from the patriarch's mouth whose humanity has already been restored to the paradisal condition. In 2 Enoch 65:8-10 Enoch tells the people that at the end all the righteous who escaped from the Lord's great judgment "will be collected together into the great age .... and they will have a great light, a great indestructible light, and paradise, great and incorruptible. For everything corruptible will pass away, and the incorruptible will come into being, and will be the shelter of the eternal residence."108

\section{Conclusion}

The limited scope of this paper did not allow the exploration of all the facets of the Adamic polemics in 2 Enoch. ${ }^{109}$ However, some conclusions can be drawn at this stage of the research. 
1. The foregoing survey testifies to the existence of Adamic polemics in 2 Enoch. These polemical developments contain, not only the "internal" debates based on 2 Enoch's depictions of the protoplast, but also the intertextual polemics with the "external" Adamic traditions attested in the primary Adam books.

2. The analysis shows that Adamic polemics involves a rewriting of "original" Adamic motifs and themes when the details of Adam's "story" are transferred to a new "hero," the seventh antediluvian patriarch Enoch.

3. The analysis demonstrates that, similar to the early booklets of 1 Enoch the attitude of the author(s) of 2 Enoch to Adam's figure and the traditions associated with his name, reminds highly polemical. Yet, in comparison with 1 Enoch, the Slavonic Enoch demonstrates a paradigm shift in polemical strategy. Now the competitive tradition is not silenced but is rather exposed and openly appropriated for polemics. This switch might be connected with the challenge which the intense development of the traditions about the exalted patriarchs and prophets posed to the "classical" profile of Enoch found in early Enochic booklets. Adamic, Mosaic, and Noachic polemics found in 2 Enoch might represent the reaction of the Enochic tradition to these new conceptual developments. It should be noted that the traditions about the elevated Adam appear to have been widespread in the Alexandrian environment of the first century $\mathrm{CE}$, the possible place and time of the composition of 2 Enoch.

4. The investigation of Adamic polemics proves that a number of important passages associated with the early Jewish mysticism, such as the motif of the Divine Face in chapters 22 and 39, the future prominent role of Enoch-Metatron as the governing power on the earth, and his title "Youth," belong to the primary text, since they play a decisive role in the original argument of the Slavonic apocalypse. In the light of this role Böttrich's hypothesis that these themes represent later interpolations must now be dismissed as erroneous.

5. The analysis of the polemical developments in the text also reveals that the theological intentions of its authors were not to find a peaceful consensus with the non-Jewish environment in the Diaspora situation, as Böttrich proposed, but to resolve the permission has been granted for this version to appear in e-Publications@ Marquette. Brill Academic Publishers does not grant permission for this article to be further copied/distributed or hosted elsewhere without the express permission from Brill Academic Publishers. 
internal problems of the Enochic tradition in its encounter with the challenges of its competitors.

\section{Notes}

${ }^{1}$ C. Böttrich, "The Melchizedek Story of 2 (Slavonic) Enoch: A Reaction to A. Orlov," JSJ 32.4 (2001) 445-70.

2 All Böttrich's criticism rests on his single erroneous assumption that 2 Enoch 71:32-33, which I used in my argument, represents an interpolation. This assumption is simply incorrect. There is nothing Christian in these two verses. They are presented in both recensions in all major MSS of 2 Enoch. A simple comparison of two recensions provides additional proof that it is not an interpolation. In the shorter recension an interpolation in 71:34-36 is absent. If 71:32-33 also belongs to this interpolation it is difficult to explain why these verses are still preserved in the shorter recension. It should be noted that previous translators A. Vaillant and F. Andersen did not consider 2 Enoch 71:31-32 as an interpolation. Cf. A. Vaillant, Le livre des secrets d'Hénoch: Texte slave et traduction française (Paris: Institut d'Etudes Slaves, 1952), 80-82; F. Andersen, "2 (Slavonic Apocalypse of) Enoch", The Old Testament Pseudepigrapha (2 vols.; ed. J. H. Charlesworth; New York: Doubleday, 1985 [1983]), 1.208 note p. It is unfortunate that Böttrich did not read my other article on the same subject (A. Orlov, "'Noah's Younger Brother': Anti-Noachic Polemics in 2 Enoch," Henoch 22.2 (2000) 259-73) where I further develop my argument about the polemical nature of the Melchizedek story of 2 Enoch on the materials of the longer recension. In this article I demonstrated the important role that 2 Enoch 71:31-32 play in the anti-Noachic polemics of the Slavonic apocalypse.

${ }^{3}$ A. Orlov, "Melchizedek Legend of 2 (Slavonic) Enoch," JSJ 31 (2000) 23-38.

${ }^{4}$ C. Böttrich, "The Melchizedek Story of 2 (Slavonic) Enoch," 465.

${ }^{5}$ It is remarkable that Böttrich's book dedicated to the Adamic tradition in 2 Enoch [C. Böttrich, Adam als Microkosmos (Judentum und Umwelt, 59; Berlin: Peter Lang, 1995)] does not have even one word on the polemical nature of the Adamic narrative in the Slavonic apocalypse. The question of the influence of the Adamic tradition on the image of Enoch is also completely ignored. permission has been granted for this version to appear in e-Publications@ Marquette. Brill Academic Publishers does not grant permission for this article to be further copied/distributed or hosted elsewhere without the express permission from Brill Academic Publishers. 
NOT THE PUBLISHED VERSION; this is the author's final, peer-reviewed manuscript. The published version may be accessed by following the link in the citation at the bottom of the page.

62 Enoch 30:8-32:2; 33:10; 41:1; 42:5; 44:1; 58:1-3; 71:28.

7 See, 1 Enoch 32:6; 37:1; 60:8; 69:9-11; 85:3; 90:37-38.

8 P. Tiller, A Commentary on the Animal Apocalypse of 1 Enoch (EJL, 4; Atlanta: Scholars, 1993), 226.

9 Tiller, 226.

10 The "humanization" of Noah is not attested in the Aramaic. See:

Tiller, 267.

11 M. Stone, "The Axis of History at Qumran," Pseudepigraphic Perspectives: The Apocrypha and the Pseudepigrapha in Light of the Dead Sea Scrolls (eds. E. Chazon and M. E. Stone; STDJ, 31; Leiden: Brill, 1999), 133-49.

${ }^{12}$ P. Alexander, "From Son of Adam to a Second God: Transformation of the Biblical Enoch," Biblical Figures Outside the Bible (ed. M. E. Stone and T. A. Bergen; Harrisburg: Trinity Press International, 1998), 102-104; H. Odeberg, 3 Enoch or the Hebrew Book of Enoch (New York: KTAV, 1973), 52-63.

${ }^{13}$ One can argue that the beginning of this process can be seen already in the Book of the Similitudes where Enoch seems to be identified with the Son of Man. It is possible that the Similitudes, written close to the time of 2 Enoch, also reflects this process of transition to the new image of Enoch. In contrast to 2 Enoch, the Similitudes, however, does not elaborate this process to the same degree as the Slavonic apocalypse does. Enoch's transformation into the Son of Man in the Similitudes 71 is rather instantaneous and ambiguous. In contrast, in 2 Enoch this process of Enoch's transition to new super-angelic identity is described in detail through the expositions of Enoch's celestial titles which unfold the patriarch's new roles in numerous celestial offices. On Enoch's transformation in the Similitudes, see J. R. Davila, "Of Methodology, Monotheism and Metatron," The Jewish Roots of Christological Monotheism. Papers from the St. Andrews Conference on the Historical Origins of the Worship of Jesus (eds. C. C. Newman, J. R. Davila, G. S. Lewis; SJSJ, 63; Leiden: Brill, 1999), 9-15; C. H. T. Fletcher-Louis, Luke-Acts: Angels, Christology and Soteriology (WUNT, 2/94; Tübingen: Mohr/Siebeck, 1997), 151; M. Knibb, "Messianism in the Pseudepigrapha in the Light of the Scrolls," DSD 2 (1995) 177-80; D. W. Suter, Tradition and Composition in the Parables of Enoch (SBLDS, 47; Missoula: Scholars, 1979), 14-23; J. VanderKam, "Righteous One, Messiah, Chosen One, and Son of Man in 1 Enoch 37-71," The Messiah: Developments in permission has been granted for this version to appear in e-Publications@ Marquette. Brill Academic Publishers does not grant permission for this article to be further copied/distributed or hosted elsewhere without the express permission from Brill Academic Publishers. 
Earliest Judaism and Christianity. The First Princeton Symposium on Judaism and Christian Origins (eds. J. H. Charlesworth, et al.; Minneapolis: Fortress, 1992), 182-3.

${ }^{14} \mathrm{P}$. Alexander observes that "the transformation of Enoch in 2 Enoch 22 provides the closest approximation, outside Merkabah literature, to Enoch's transformation in 3 Enoch 3-13." P. Alexander, "3 (Hebrew Apocalypse of) Enoch," The Old Testament Pseudepigrapha (2 vols,; ed. J. H. Charlesworth; New York: Doubleday, 1985 [1983]), 1.248. ${ }^{15}$ M. Idel, "Enoch is Metatron," Immanuel 24/25 (1990) 220-240. The original Hebrew version of this article appeared in: Early Jewish Mysticism (ed. J. Dan; Jerusalem, 1987). ${ }^{16}$ Idel points to one of such accounts, the Armenian text known as "The Words of Adam and Seth" where the following tradition can be found: "But he [Adam], not having observed the commandments, and having been stripped of the divine light, and having been thrown outside the Garden, became an equal of the dumb beast. And Enoch considered these things, and for forty days and for forty nights he did not eat at all. And after this he planted a luscious garden, and he planted in it fruit bearers and he was in the garden for five hundred and forty-two years, and after that, in body, he was taken up to heaven, and was found worthy of the divine glory and light." Michael E. Stone, Armenian Apocrypha Relating to the Patriarchs and Prophets (Jerusalem, 1982), 12-13.

${ }^{17}$ It should be noted that rabbinic and Samaritan literature often depict Moses as a luminous counterpart of Adam who acquired a luminous garment during his encounter with the Lord on Mount Sinai.

18 M. Idel, "Enoch is Metatron," 224.

${ }^{19}$ P. Alexander, "From Son of Adam to a Second God: Transformation of the Biblical Enoch," in: Biblical Figures Outside the Bible (ed. M. E. Stone and T. A. Bergen; Harrisburg: Trinity Press International, 1998), 111.

${ }^{20}$ P. Alexander, "From Son of Adam to a Second God," 111.

${ }^{21}$ It should be noted that the Adamic tradition is not the only "building material" used in 2 Enoch in order to create the new, celestial image of Enoch. There is also a strong presence of the traditions about the elevated Moses which help to enhance Enoch's new identity in various theophanic settings throughout the text. On the Mosaic traditions in 2 Enoch see, A. Orlov, "Ex 33 on God's Face: A Lesson from the Enochic Tradition," Seminar Papers 39, Society of Biblical Literature Annual

Journal for the Study of Judaism, Vol. 34, No. 3 (2003): pg. 274-303. DOI. This article is @ Brill Academic Publishers and permission has been granted for this version to appear in e-Publications@ Marquette. Brill Academic Publishers does not grant permission for this article to be further copied/distributed or hosted elsewhere without the express permission from Brill Academic Publishers. 
Meeting 2000 (Atlanta: Society of Biblical Literature, 2000), 130-147; idem, "The Face as the Heavenly Counterpart of the Visionary in the Slavonic Ladder of Jacob," in: Of Scribes and Sages: Early Jewish Interpretation and Transmission of Scripture (2 vols.; ed. C. A. Evans; Studies in Scripture in Early Judaism and Christianity, 9; London: T\&T Clark, 2004), 2.59-76.

${ }^{22}$ Slav. $\chi \alpha \rho \mid \zeta \varepsilon \mu \lambda$. M. I Sokolov, "Materialy i zametki po starinnoj slavjanskoj literature. Vypusk tretij, VII. Slavjanskaja Kniga Enoha Pravednogo. Teksty, latinskij perevod i izsledovanie. Posmertnyj trud avtora prigotovil k izdaniju M. Speranskij," COIDR 4 (1910), 1.30. ${ }^{23}$ On the connections between the Genesis account and the Adamic story of 2 Enoch, see: J. T. A. G. M. van Ruiten, "The Creation of Man and Woman in Early Jewish Literature," The Creation of Man and Woman: Interpretations of the Biblical Narratives in Jewish and Christian Traditions (ed. G. P. Luttikhuizen; TBN, 3; Leiden: Brill, 2000), 34-62.

${ }^{24}$ Andersen, 1.184 .

${ }^{25}$ Andersen, 1.185 .

${ }^{26}$ Cf. Philo, Opif. 88 "So the Creator made man after all things, as a sort of driver and pilot, to drive and steer the things on earth, and charged him with the care of animals and plants, like a governor subordinate to the chief and great King." Philo (trs. F. H. Colson and G. H. Whitaker; 11 vols.; Cambridge, Massachusetts: Harvard University Press, 1949), 1.73. See, also: J. R. Levison, Portraits of Adam in Early Judaism: From Sirach to 2 Baruch (JSPSS, 1; Sheffield: Sheffield Academic Press, 1988), 66-68.

${ }^{27}$ Adam's designation as the second angel in 2 Enoch 30:11 also seems to point to the protoplast's role as the viceroy of God. Cf. Philo, Opif. 148 "... and the first man was wise with a wisdom learned from and taught by Wisdom's own lips, for he was made by divine hands; he was, moreover, a king, and it befits a ruler to bestow titles on his several subordinates. And we may guess that the sovereignty with which that first man was invested was a most lofty one, seeing that God had fashioned him with the utmost care and deemed him worthy of the second place, making him His own viceroy and the lord of all others." Philo 1.117. It is also important that in 2 Enoch the realm of Adam's dominion is designated as another world: "And the devil understood how I wished to create another world, so that everything could be subjected to Adam on the earth, to rule and reign over it." 2 permission has been granted for this version to appear in e-Publications@ Marquette. Brill Academic Publishers does not grant permission for this article to be further copied/distributed or hosted elsewhere without the express permission from Brill Academic Publishers. 
NOT THE PUBLISHED VERSION; this is the author's final, peer-reviewed manuscript. The published version may be accessed by following the link in the citation at the bottom of the page.

Enoch 31:3. Andersen, 1.154.

282 Enoch 39:8 (the longer recension). Andersen, 1.164.

${ }^{29}$ Slav. $\left.\pi \rho \varepsilon \delta \lambda \imath \chi \varepsilon \mu \chi \alpha \rho\right\} \zeta \varepsilon \mu \nu \alpha \gamma o$.

302 Enoch 39:8. Andersen, 1.165.

31 "Listen, my people, and give heed to the utterance of my lips! If to an earthly king someone should bring some kinds of gifts, if he is thinking treachery in his heart, and the king perceives it, will he not be angry with him?" Andersen, 1.172.

32 Andersen, 1.217.

33 I am indebted to Professor James VanderKam for this clarification.

${ }^{34}$ Although Enoch's role as the governing power on earth is unknown in the early Enochic materials, it does not mean that such a designation of Enoch in the Slavonic apocalypse is a foreign interpolation invented by the Greek or Slavic scribes. It appears that the depiction of Enoch as the governing power on earth represents an important step in shaping the new image of Enoch as the supreme angel elevated above the angelic world. The role of Enoch as the king/manager of earth in 2 Enoch is, therefore, directly connected with the later Metatron title, the "Prince of the World," found in the Merkabah literature and on the incantation bowls from Babylonia. Cf. Alexander, "3 Enoch," 1.229, 1.243; C.H. Gordon, "Aramaic and Mandaic Magical Bowls," ArOr 9 (1937) 94-95. The Merkabah tradition stresses the role of Enoch-Metatron as the governing power over the nations, kingdoms, and rulers on earth. Chapter 30 of 3 Enoch alludes to the role of Metatron as the Prince of the World, the leader of seventy-two princes of kingdoms in the world who speaks (pleads) in favor of the world before the Holy One ... every day at the hour when the book is opened in which every deed in the world is recorded. The depiction of Metatron as the "Prince of the World" in 3 Enoch reveals several similarities to the royal status of Enoch in the Slavonic apocalypse. One of them is that in 2 Enoch 64:1 the patriarch delivers his address "to his sons and to the princes of the people." The reference to the princes of the people is intriguing since in 3 Enoch 30 Metatron is described as the leader of seventy-two princes of the kingdoms of the world. The second important similarity is that in both texts the role of Enoch/Metatron as the governing power on earth is tied to his duties as the witness of the divine judgment. Both accounts, therefore, contain references to Enoch's writings representing the record of all the deeds of every person.

Journal for the Study of Judaism, Vol. 34, No. 3 (2003): pg. 274-303. DOI. This article is @ Brill Academic Publishers and permission has been granted for this version to appear in e-Publications@ Marquette. Brill Academic Publishers does not grant permission for this article to be further copied/distributed or hosted elsewhere without the express permission from Brill Academic Publishers. 
35 Andersen, 1.164-166. In chapter 43, the same picture can be observed. Enoch's measuring activities follow his definition as the governor/manager of the earth.

${ }^{36}$ It should be noted that this role of Enoch as the measurer of the earthly things is unknown in the early Enochic booklets of 1 Enoch where Enoch's functions as the heavenly scribe are limited to the meteorological, calendarical and astronomical matters.

37 C. Böttrich, Weltweisheit, Menschheitsethik, Urkult: Studien zum slavischen Henochbuch (WUNT, 2/50; Tübingen: Mohr/Siebeck, 1992), 113-14.

${ }^{38}$ C. Böttrich, Weltweisheit, Menschheitsethik, Urkult, 113. Cf. also, C. Böttrich, "Beobachtungen zum Midrash vom 'Leben Henochs'," Mitteilungen und Beiträge der Forschungsstelle Judentum an der Theologischen Fakultät Leipzig 10 (1996), 44-83.

39 M. E. Stone, "The Fall of Satan and Adam's Penance: Three Notes on the Books of Adam and Eve," JTS 44 (1993) 143-156.

40 This does not mean that 2 Enoch is literally dependent on the primary Adam books in their final form, but rather indicates that the traditions which stand behind these books have ancient origins since, by the first century $\mathrm{CE}$, these traditions were already appropriated into the Enochic text.

41 Andersen, 1.138.

42 Andersen, 1.138.

43 The Adamic story of the angelic veneration of Adam and Satan's disobedience is attested in many Jewish, Christian and Muslim materials. Cf. Slavonic version of 3 Baruch 4; Gos. Bart. 4, Coptic Enthronement of Michael, Cave of Treasures 2:10-24; Koran 2:31-39; 7:11-18; 15:31-48; 17:61-65; 18:50; 20:116-123; 38:71-85.

44 W. R. Morfill and R. H. Charles, The Book of the Secrets of Enoch (Oxford: Oxford University Press, 1896), 28.

45 M. E. Stone, "The Fall of Satan and Adam's Penance: Three Notes on the Books of Adam and Eve," Literature on Adam and Eve. Collected Essays (eds. G. Andersen, M. Stone, J. Tromp; SVTP, 15; Brill: Leiden, 2000), 47.

46 M. E. Stone, "The Fall of Satan and Adam's Penance," 48.

47 Stone, The Fall of Satan and Adam's Penance," 48.

48 M. Stone's argument was later supported and developed by G. Anderson. G. Anderson observes that "one cannot imagine that the tradition in the Enoch materials was created independently from the permission has been granted for this version to appear in e-Publications@ Marquette. Brill Academic Publishers does not grant permission for this article to be further copied/distributed or hosted elsewhere without the express permission from Brill Academic Publishers. 
tradition found in the Vita." G. Anderson, "The Exaltation of Adam and the Fall of Satan," Literature on Adam and Eve, 101.

49 Stone, "The Fall of Satan and Adam's Penance," 48.

50 Stone, "The Fall of Satan and Adam's Penance," 48.

51 Andersen, 1.114.

52 Andersen, 1.114.

532 Enoch 18:3 "And those men answered me, 'These are the Grigori, who turned aside from the Lord, 200 myriads, together with their prince Satanail. And similar to them are those who went down as prisoners in their train, who are in the second heaven, imprisoned in great darkness.'" Andersen, 1.130. It is noteworthy that in 2 Enoch the Enochic story of the Watchers' rebellion and the Adamic story of Satan's refusal to venerate humanity appear to be closely connected. They demonstrate an intriguing parallel to the Midrash of Shemhazai and Azael 2, 3 Enoch 5:9-10 and thr Zohar III.207b-208a, where the leaders of the Watchers are depicted as the forces opposing the creation and elevation of humanity.

54 G. Anderson, "The Exaltation of Adam and the Fall of Satan," Literature on Adam and Eve, 83-110. On the Adamic traditions in rabbinic literature see, also: A. Altmann, "The Gnostic Background of the Rabbinic Adam Legends," JQR 35 (1945) 371-391; B. Barc, "La taille cosmique d'Adam dans la littérature juive rabbinique des trois premiers siècles après J.-C.," RSR 48 (1975) 173-85; J. Fossum, "The Adorable Adam of the Mystics and the Rebuttals of the Rabbis," Geschichte-Tradition-Reflexion. Festschrift für Martin Hengel zum 70. Geburtstag (2 vols. eds. H. Cancik, H. Lichtenberger and P. Schäfer; Tübingen: Mohr/Siebeck, 1996), 1.529-39; P. Schäfer, Rivalität zwischen Engeln und Menschen: Untersuchungen zur rabbinischen Engelvorstellung (SJ, 8; Berlin: de Gruyter, 1975); A. Segal, Two Powers in Heaven. Early Rabinnic Reports About Christianity and Gnosticism (SJLA, 25; Leiden: Brill, 1977), 108-115.

${ }^{55}$ For the similar tradition see: the Midrash of Shemhazai and Azael 2, and the Zohar III.207b-208a.

56 P. Alexander, "3 (Hebrew Apocalypse of) Enoch," 1.258-59.

57 G. Anderson, "The Exaltation of Adam and the Fall of Satan," Literature on Adam and Eve, 107.

$58 \mathrm{G}$. Anderson, "The Exaltation of Adam and the Fall of Satan," Literature on Adam and Eve, 108.

59 Slav. Jvo) $\varepsilon$. permission has been granted for this version to appear in e-Publications@Marquette. Brill Academic Publishers does not grant permission for this article to be further copied/distributed or hosted elsewhere without the express permission from Brill Academic Publishers. 
NOT THE PUBLISHED VERSION; this is the author's final, peer-reviewed manuscript. The published version may be accessed by following the link in the citation at the bottom of the page.

60 Professor Francis Andersen reassured me in a private communication about the originality of this reading, referring to it as "powerful evidence."

${ }^{61}$ See, for example, Synopse, §§384; 385; 390; 396. Peter Schäfer, with M. Schlüter and H.G. von Mutius, Synopse zur Hekhalot-Literatur (TSAJ, 2; Tübingen: Mohr/Siebeck, 1981), 162-3, 164-5, 166-7.

62 Andersen, 1.118-9.

63 M.I. Sokolov, "Materialy i zametki po starinnoj slavjanskoj literature," 85.

64 Andersen, 1.119.

65 Alexander, 3 Enoch, 1.257.

66 M.I. Sokolov, "Materialy i zametki po starinnoj slavjanskoj literature," 90-91; Andersen, 1.119.

67 I want to express my deep appreciation to Professor Francis Andersen who generously shared with me the microfilms and photographs of MSS V, R, and J.

68 Unfortunately, Friedrich Repp's research on the Vienna Codex failed to discern the proper meaning of "youth" in this important manuscript. See: F. Repp, "Textkritische Untersuchungen zum Henoch-Apokryph des co. slav. 125 der Österreichischen Nationalbibliothek," Wiener slavistische Jahrbuch 10 (1963) 65.

69 Slav. J vo/s.

70 Ms. V (VL 125) [Nr. 3], fol. 317.

71 Andersen, 1.93-94.

72 On the hunger motif in the primary Adam books, see: G. Anderson, "The Penitence Narrative in the Life of Adam and Eve," Literature on Adam and Eve,6ff.

73 "They arose and went about upon the earth, and they did not find food like the food by which they had been nourished in [the Garden]." A Synopsis of the Books of Adam and Eve. Second Revised Edition (eds. G. A. Anderson and M. E. Stone; Early Judaism and Its Literature, 17; Atlanta: Scholars, 1999), 3E.

74 Andersen, 1.183.

${ }^{75}$ A Synopsis of the Books of Adam and Eve, 5E.

76 "I saw the view of the face of the Lord, like iron made burning hot in a fire and brought out, and it emits sparks and is incandescent. Thus even I saw the face of the Lord. But the face of the Lord is not to be talked about, it is so very marvelous and supremely awesome and supremely frightening. And who am I to give an account of the permission has been granted for this version to appear in e-Publications@Marquette. Brill Academic Publishers does not grant permission for this article to be further copied/distributed or hosted elsewhere without the express permission from Brill Academic Publishers. 
incomprehensible being of the Lord, and of his face, so extremely strange and indescribable? And how many are his commands, and his multiple voice, and the Lord's throne, supremely great and not made by hands, and the choir stalls all around him, the cherubim and the seraphim armies, and their never-silent singing. Who can give an account of his beautiful appearance, never changing and indescribable, and his great glory? And I fell down flat and did obeisance to the Lord" (2 Enoch 22:1-4, the longer recension). Andersen, 1.136.

77 Andersen, 1.139.

782 Enoch's narrative gives evidence that Enoch's face acquired the same qualities of luminosity as the Face of the Lord. In 2 Enoch 37, the Lord calls one of his angels to chill the face of Enoch before his return to earth. The angel, who "appeared frozen," then chilled Enoch's face with his icy hands. Immediately after this procedure, the Lord tells Enoch that if his face had not been chilled in such a way, no human being would be able to look at his face. This chilling procedure indicates that Enoch's metamorphosis near the Face involves the transformation of the visionary's face into the fiery, perilous entity which now resembles the Lord's Face. We can find a detailed description of this process in another "Enochic" text, Sefer Hekhalot, which describes the transformation of Enoch-Metatron, the Prince of the Divine Presence, into a fiery creature. Cf. 3 Enoch 15:1 "R. Ishmael said: The angel Metatron, Prince of the Divine Presence, the glory of highest heaven, said to me: When the Holy One, blessed be he, took me to serve the throne of glory, the wheels of the chariot and all needs of the Shekinah, at once my flesh turned to flame, my sinews to blazing fire, my bones to juniper coals, my eyelashes to lightning flashes, my eyeballs to fiery torches, the hairs of my head to hot flames, all my limbs to wings of burning fire, and the substance of my body to blazing fire." 3 Enoch 15:1. Alexander, 3 Enoch, 1.267.

79 It is noteworthy that after this procedure Enoch's "face," just as the Lord's face acquired the ability to glorify other subjects. Thus in 2 Enoch 64:3-5 the following tradition can be found: "... and the elders of the people and all the community came and prostrated themselves and kissed Enoch... O our father Enoch, bless your sons and all the people, so that we may be glorified in front of your face today." Andersen, 190.

80 Andersen, 1.170.

${ }^{81}$ Andersen, 1.171 , note b.

Journal for the Study of Judaism, Vol. 34, No. 3 (2003): pg. 274-303. DOI. This article is @ Brill Academic Publishers and permission has been granted for this version to appear in e-Publications@ Marquette. Brill Academic Publishers does not grant permission for this article to be further copied/distributed or hosted elsewhere without the express permission from Brill Academic Publishers. 
82 See: C. Böttrich, Weltweisheit, Menschheitsethik, Urkult,112-113. $83 \mathrm{G}$. Scholem was the first to propose that the expression "the extent of the Lord" found in 2 Enoch 39 might reflect the exact terminology found in the Shicur Qomah materials. Cf. Scholem's lecture "The Age of Shicur Qomah Speculation and a Passage in Origen," G. Scholem, Jewish Gnosticism, Merkabah Mysticism, and Talmudic Tradition (New York: The Jewish Theological Seminary, 1965); idem, On the Mystical Shape of the Godhead: Basic Concepts in the Kabbalah (New York, Schocken, 1991), 29.

84 C. Böttrich, Adam als Microkosmos (Judentum und Umwelt, 59; Berlin: Peter Lang, 1995).

85 Andersen, 1.138.

86 Andersen, 1.114.

87 Andersen, 1.117.

${ }^{88}$ A Synopsis of the Books of Adam and Eve, 45E (Armenian version). 89 A Synopsis of the Books of Adam and Eve, 45E (Armenian version). 90 43(13): "The Lord said, 'I will admit them into the Garden and I will anoint them with that unction.'" A Synopsis of the Books of Adam and Eve, 45E (Georgian version).

91 M. Stone, "The Angelic Prediction in the Primary Adam Books," Literature on Adam and Eve, 127.

92 H. E. Gaylord, "3 (Greek Apocalypse of) Baruch," The Old Testament Pseudepigrapha (2 vols; ed. J. H. Charlesworth; New York: Doubleday, 1985 [1983]), 1.658.

93 Cf. M. Stone, "The Angelic Prediction in the Primary Adam Books," Literature on Adam and Eve, 126.

94 E. C. Quinn, The Quest of Seth for the Oil of Life (Chicago: The University of Chicago Press, 1962), 59.

95 A Synopsis of the Books of Adam and Eve, 40E.

96 M. Stone, "The Angelic Prediction in the Primary Adam Books," Literature on Adam and Eve, 126.

97 P. Alexander, "From Son of Adam to a Second God: Transformation of the Biblical Enoch," Biblical Figures Outside the Bible (ed. M. E. Stone and T. A. Bergen; Harrisburg: Trinity Press International, 1998), 111.

98 Andersen, 1.190.

99 The designation of Enoch as "our father" here and in 2 Enoch 69:2, 69:5, 70:3 might have a polemical flavor. In 2 Enoch 58:1 Adam is also designated as "our father." In WisSol 10:1 the title "the Father of permission has been granted for this version to appear in e-Publications@Marquette. Brill Academic Publishers does not grant permission for this article to be further copied/distributed or hosted elsewhere without the express permission from Brill Academic Publishers. 
the World" is applied to the protoplast. See, P. B. Munoa III, Four Powers in Heaven. The Interpretation of Daniel 7 in the Testament of Abraham (JSPSS, 28; Sheffield: Sheffield Academic Press, 1998), 1045.

100 Andersen, 1.190.

${ }^{101}$ C. Böttrich, Weltweisheit, Menschheitsethik, Urkult, 194-95. C. Böttrich, "The Melchizedek Story of 2 (Slavonic) Enoch: A Reaction to A. Orlov," JJS 32.4 (2001) 457.

1022 Enoch 53:1-4. See also7:4-5, 62:2.

103 Slav. \}ııı $\varepsilon \lambda$ ) - literally "the one who has taken away." Sokolov, Slavjanskaja Kniga Enoha Pravednogo, 1.59; 1.101. The noun $\} 1 \mu 1 \tau \varepsilon \lambda$ ) derives from the verb o $\psi \mu \mu \alpha \tau$, o $\tau \mu \alpha \tau$ (to remove, to release) which among other meanings can be used in the expression "to release from sin." Barhudarov's dictionary relates отıнатı to the Greek a) fairei n. S. G. Barhudarov, ed., Slovar' russkogo jazyka XI-XVII vekov (25 vols.; Moscow: Nauka, 1975ff) 14.74-75.

${ }^{104}$ Another important hint that Enoch was able to take away the sin of the protoplast is that the MSS of the longer recension speak, not about many sins, but about only one sin, "the sin of [hu]mankind." In contrast, the reading of the shorter recension, which uses a plural form-"our sins," is clearly secondary.

105 The important hint to this unique role is Enoch's definition in 2 Enoch 64 as "the one whom the Lord chose in preference to all the people of the earth."

106 Andersen, 1.190.

107 Andersen, 1.190.

108 Andersen, 1.192.

109 One of these unexplored subjects includes the connection between the tradition of Adam's cosmic body in 2 Enoch 30 and the role of Enoch as the measurer of the divine body in 2 Enoch 39. Unfortunately, this lengthy investigation cannot be included in this paper and will be published separately. permission has been granted for this version to appear in e-Publications@ Marquette. Brill Academic Publishers does not grant permission for this article to be further copied/distributed or hosted elsewhere without the express permission from Brill Academic Publishers. 